\title{
The mechanical performance of glass fibre reinforced composite based sandwich structure
}

\author{
Xiaoli Zhu \\ Jiyuan Vocational and Technical College, the Southeast corner of Donghuan \\ Road and Huanghe Avenue, Qinyuan Street, Jiyuan, Henan 459000, China
}

Received July 21, 2018

\begin{abstract}
In this study, a sandwich structure of composite material based on glass fiber was proposed. Its bending properties were investigated, the strength and thermal properties of the sandwich structure and the materials of its components were tested. The results showed that the maximum bending load of the sandwich was $250 \mathrm{~N}, 500 \mathrm{~N}$ and $1000 \mathrm{~N}$, respectively, when the density of the core material was $50 \mathrm{~kg} / \mathrm{m}^{3}, 75 \mathrm{~kg} / \mathrm{m}^{3}$ and 100 $\mathrm{kg} / \mathrm{m}^{3}$. The temperature had a slight effect on the tensile property of the PU core material, the ultimate tensile load of the sandwich, whose core material density was 100 $\mathrm{kg} / \mathrm{m}^{3}$, was $106 \mathrm{~N}, 98 \mathrm{~N}, 93 \mathrm{~N}$ and $61 \mathrm{~N}$, respectively, when the temperature was $20{ }^{\circ} \mathrm{C}$, $40{ }^{\circ} \mathrm{C}, 60{ }^{\circ} \mathrm{C}$ and $80{ }^{\circ} \mathrm{C}$. The peak value of the rate of energy release of the deformation of the sandwich interface increased with increasing temperature, and the peak value occurred when the crack shifted $40 \sim 50 \mathrm{~mm}$. At temperatures above $80{ }^{\circ} \mathrm{C}$, the resin used in adhesion of the surface evolved from a glassy state to a highly elastic state.
\end{abstract}

Keywords: glass fibre, composite material, bending property, tensile property.

Предложена сэндвич-структура из композитного материала на основе стекловолокна. Исследованы его свойства на изгиб, испытаны прочностные и тепловые свойства сэндвич структуры и материалов, её составляющих. Результаты показали, что максимальная изгибающая нагрузка сэндвича составляла $250 \mathrm{H}, 500 \mathrm{H}$ и $1000 \mathrm{H}$ соответственно, когда плотность материала сердцевины составляла $50 \mathrm{kr} / \mathrm{m}^{3}, 75 \mathrm{\kappa r} / \mathrm{m}^{3}$ и $100 \mathrm{\kappa r} / \mathrm{m}^{3}$. Температура несущественно влияет на растягивающее свойство материала сердцевины PU. Предельная растягивающая нагрузка сэндвича, плотность материала сердцевины которого составляла $100 \mathrm{\kappa г} / \mathrm{m}^{3}$, равнялась $106 \mathrm{H}, 98 \mathrm{H}, 93 \mathrm{H}$ и $61 \mathrm{H}$ соответственно при температуре 20 ${ }^{\circ} \mathrm{C}, 40{ }^{\circ} \mathrm{C}, 60{ }^{\circ} \mathrm{C}$ и $80{ }^{\circ} \mathrm{C}$. При температуре выше $80{ }^{\circ} \mathrm{C}$ смола, используемая при адгезии поверхности, превратилась из стеклообразного состояния в высокоэластичное состояние.

Механічні характеристики багатошарової структури на основі композитного матеріалу на основі скловолокна. Xiaoli Zhu

Запропоновано сендвіч-структуру з композитного матеріалу на основі скловолокна. Досліджено його властивості на вигин, випробувано на міцність і теплові властивості сендвіч структури і матеріалів її складових. Результати показали, що максимальне згинаюче навантаження сендвіча становило $250 \mathrm{H}, 500 \mathrm{H}$ і $1000 \mathrm{H}$ відповідно, коли щільність матеріалу серцевини становила $50 \mathrm{kr} / \mathrm{m}^{3}, 75 \mathrm{kr} / \mathrm{m}^{3}$ i $100 \mathrm{\kappa r} / \mathrm{m}^{3}$. Температура несуттєво впливала на розтяжну властивість матеріалу серцевини PU. Граничне розтягуюче навантаження сендвіча, щільність матеріалу серцевини якого становила 100

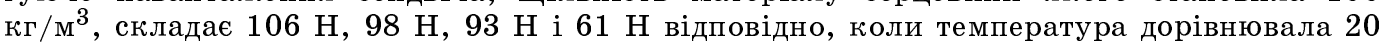
${ }^{\circ} \mathrm{C}, 40{ }^{\circ} \mathrm{C}, 60{ }^{\circ} \mathrm{C}$ і $80{ }^{\circ} \mathrm{C}$. При температурі вище $80^{\circ} \mathrm{C}$ смола, яка використовується при адгезії поверхні, перетворилася з склоподібного стану у високоеластичний стан.

\section{Introduction}

Composite material is widely used in various branches of engineering [4], in particular in construction for the replacement of reinforced concrete is used a composite of fiberglass, which has low weight and high strength. The upper and lower cladding of sandwich plates made of fiberglassreinforced composite is a glass fiber fabric 
that does not contain alkali, the material of the middle core is polyurethane foam (PU), and the binder between the core and the skin is unsaturated polyester resin [5].

There is a considerable amount of studies concerning the mechanical properties of glass fiber reinforced composites. Das et al. [1] has studied the fracture properties of a new type of sustainable glass fiber reinforced composite which was made of waste iron powder and other ingredients through anoxic carbonization at room temperature, compared it with ordinary Portland cement, and found that the fracture toughness of the composite was stronger than that of the cement and larger particles of metallic iron was more beneficial to the fracture toughness. Mostafa et al. [2] develop a composite sandwich plate for sailing ship hull by taking glass fiber epoxy composite as the skin and polyurethane foam as the core material and test the bending performance of the sandwich plate using fourpoint bending test. The results showed that the sandwich plate was linear elastic at the beginning and then nonlinear elastic, which was consistent with the prediction results of the classical sandwich theory.

Bal et al. [3] made a sandwich plate by taking glass fibre cloth as the upper and lower skins, poplar veneer as the core material and phenol glue as the binder and tested its bending properties. The results showed that the vertical fracture modulus and modulus of elasticity of the sandwich plate were higher than those of the ordinary wood board. In this study, a microcomputer controlled electronic universal testing machine was used to perform the three-point bending test on glass fiber reinforced composite sandwich containing different density of PU foam, the tensile properties of the PU foam at a certain density at different temperatures and the tensile properties of the sandwich containing PU foam at that density at different temperatures were measured, and the strain energy release rate was analyzed.

\section{Theory of mechanical properties of sandwich structure of composite material}

\subsection{Theoretical analysis of bending per-}

\section{formance}

Glass fibre enhanced composite sandwich was the research subject of this study. Though the used material is novel, it is an ordinary foam sandwich structure. Therefore the failure theory of ordinary form sandwich structure could be used for analysis [14].
The theoretical model of indentation failure of ordinary foam core sandwich is shown in Fig. 1. Suppose glass fibre panel as an ideal elastic material and bind well with the core material. Stress is analyzed when three-point bending action was performed on the sandwich [15], and the following equation [7] is obtained.

$$
\begin{gathered}
q=\frac{d W}{d s}=\sigma \beta, \\
N \frac{d u}{d s}+W=\frac{d M}{d s}, \\
M=-(E I)_{f}^{\prime} \frac{d^{2} u}{d s^{2}},
\end{gathered}
$$

where $q$ stands for lateral load per unit length, $W$ stands for the shear force inside glass fibre panel, $N$ stands for the axial force inside glass fibre panel, $M$ stands for the sectional bending moment of glass fibre panel, and $(E I)_{f}^{\prime}$ stands for the bending rigidity of glass fibre panel. Equation (1), (2) and (3) were simultaneous and solved, and then we have

$u=H \cos (k s)+O \sin (k s)+J s+K-\frac{\sigma \beta s^{2}}{2 N}$,

where

$$
\begin{gathered}
k=\sqrt{\frac{N}{(E I)_{f}^{\prime}}}, \\
N=\frac{Q m}{4 r}, \\
H=\frac{2 r}{m k}\left(\frac{1-\cos \omega-\omega \sin \omega}{\sin \omega-w \cos \omega}\right), \\
O=-\frac{2 r}{m k}, \\
K=\frac{2 r}{m k}\left(\frac{1-\cos \omega-\omega \sin \omega}{\sin \omega-w \cos \omega}\right)+ \\
+\frac{r \omega^{2}}{m k}\left(\frac{1+\cos \omega}{\sin \omega-w \cos \omega}\right)
\end{gathered}
$$

Then it is simplified according to $\omega=k a$ :

$$
Q=\beta t_{f}^{\prime} \sqrt[3]{\frac{4 r E_{f}^{\prime} \sigma^{2}}{3 m}\left(\frac{\sin \omega-\omega \cos \omega}{1-\cos \omega}\right)},
$$


$Q$ was largest when $\omega=\pi$, i.e., the ultimate load of bending:

$$
Q_{\max }=\beta t_{f}^{\prime} \sqrt[3]{\frac{\pi^{2} r E_{f}^{\prime} \sigma^{2}}{3 m}} .
$$

\subsection{Theoretical analysis of tensile per- formance}

Tensile performance refers to the ability of ensuring no damages on materials under outward tension. The size of such an ability is equal to the size of tension at the moment when the structure of a material is damaged. Before determining the load at the moment when the composite sandwich delaminated, the energy needed by damaging the structure should be determined at first. In this study, the strain energy release rate $E_{\text {out }}$ was calculated using yield scale method [9]. Suppose flexibility $A=x / F \quad$ (the ratio of displacement to load) was in proportion to $\alpha^{\prime \prime}$; least square fitting was performed on $\lg A$ and $\lg \alpha$, and the straight slope was expressed as index $n$. Then the strain energy release rate could be expressed as [8]:

$$
E_{\text {out }}=\frac{n F x}{2 L l},
$$

where $L$ stands for the width of the test specimen and $l$ stands for the length of crack.

But in the actual test of this study, the end block of the test specimen might rotate when deflection occurred; as a result, the actual displacement was smaller than the theoretical displacement. Therefore linear displacement needed to be corrected using correction factor B. The formula of correction factor B [10] was:

$$
B=1-\left(\frac{d_{2}}{l}\right)^{3}-\frac{9}{8} \frac{x d_{1}}{l^{2}}\left[1-\left(\frac{d_{2}}{l}\right)^{2}\right]-\frac{9}{35}\left(\frac{x}{l}\right)^{2},
$$

where $\left(\frac{d_{2}}{l}\right)^{3}$ was used for correcting the rigidity of block whose the rotation effect was ignored, $\frac{9}{8} \frac{x d_{1}}{l^{2}}\left[1-\left(\frac{d_{2}}{l}\right)^{2}\right]$ was used for correcting the lever and end block rigidity of which changed because of the rotation of end block, $\frac{9}{35}\left(\frac{x}{l}\right)^{2}$ was used for correcting the large displacement in the lever, and $d_{1}$ and $d_{2}$ stand for the thickness and width of the clamp which was used for fixing test specimen respectively. The correction factor could also be used for correcting flexibility.

Lead terminal was used in the test. Therefore the large displacement produced by the lever was smaller than the crack of the test specimen, and the load had obvious displacement. To correct the deviation, correction factor $D$ was introduced, and its formula [11] was:

$$
D=1-\frac{3}{10}\left(\frac{x}{l}\right)^{2}-\frac{3}{2}\left(\frac{x d_{1}}{l^{2}}\right),
$$

where $\frac{3}{10}\left(\frac{x}{l}\right)^{2}$ was used for correcting large displacement and $\frac{3}{2}\left(\frac{x d_{1}}{l^{2}}\right)$ was used for correcting the rotation of lead terminal. The actual lever arm $l^{\prime}=l \sqrt{D}$.

In conclusion, strain energy release rate was in proportion to the squared value of momentum of structural layering, and it could be corrected by multiplying correction factor $D$ according to the theory of small displacement $E_{\text {out }}$.

\section{Experimental}

The properties of the raw materials of glass fibre composite sandwich are shown in Table 1.

To detect the tensile strength of $\mathrm{PU}$ under different temperatures, a PU cube which was in a size of $60 \mathrm{~cm} \times 60 \mathrm{~cm} \times 60 \mathrm{~cm}$ and whose density was $100 \mathrm{~kg} / \mathrm{m}^{3}$ was embedded with a thermocouple transducer and connected with an intelligent temperature inspecting instrument to obtain the internal temperature of the form. The temperature of the test specimen should be up to the requirement during experiment. There were four test specimens.

Glass fibre composite sandwich was manufactured [13]. Firstly PU at different density were cut into pieces in a size of $250 \mathrm{~mm} \times 70 \mathrm{~mm}$ and $60 \mathrm{~mm}$. Then the upper and lower surfaces were coated with unsaturated polyester resin. Two layers of $0^{\circ} / 90^{\circ}$ alkali-free glass fibre cloth were pasted on the upper and lower surfaces of the foam. Then the surfaces were coated with resin.

Loading test was performed following ASTM C393-62 [12] and using three-point bending method. WDW-300D microcomputer control electron universal testing ma- 
Xiaoli Zhu / The mechanical performance of ...

Table 1. The properties of the raw materials of glass fibre composite sandwich

\begin{tabular}{|c|c|c|}
\hline Components & Density & Tensile strength \\
\hline Biaxial type E alkali-free glass fibre cloth & $800 \mathrm{~g} / \mathrm{m}^{2}$ & $3.5 \mathrm{GPa}$ \\
PU & $100,75,50 \mathrm{~kg} / \mathrm{m} 3$ & $\backslash$ \\
Unsaturated polyester resin & $\backslash$ & $60-85 \mathrm{MPa}$ \\
\hline
\end{tabular}

chine (Jinan Hensgrand Instrument Co., Ltd., China) was used, and the loading speed was 3 $\mathrm{mm} / \mathrm{min}$. Firstly the test specimen was preloaded, and the loading capacity was $25 \%$ of the theoretical value of the ultimate load. Then it was set as 0 , and loading started again. Loading stopped if the structure of the test specimen was damaged.

Tensile test on PU: The aforementioned microcomputer control electron universal testing machine was used. The temperature of the test was provided by the self-contained temperature box. Firstly the foam was connected with the loading block which was used for tension using structural adhesive. After complete solidification of the structural adhesive, the temperature in the temperature box was improved and kept at the level which was required by the test using temperature control system. The PU which was embedded with a sensor was put into the temperature box and was fixed by the internal tension loading head. The internal temperature of the PU was detected using the intelligent temperature inspecting instrument which was connected with the sensor. When the internal temperature was the same with the temperature inside the temperature box, loading started in a speed of $3 \mathrm{~mm} / \mathrm{min}$. Loading stopped if the structure was damaged. The test temperature was $20,40,60$ and $80{ }^{\circ} \mathrm{C}$, respectively.

Tensile test on the glass fiber reinforced composite sandwich whose density of core material was $100 \mathrm{~kg} / \mathrm{m}^{3}$ : The setting of the test equipment and the placement of the test specimen were the same with the last test. When the internal temperature of the test specimen was the same with the temperature inside the temperature box, loading started at a speed of $3 \mathrm{~mm} / \mathrm{min}$. Loading stopped when the fiber cloth was stripped to the $2 / 3$ of the sandwich. The displacement curve was automatically recorded by a computer.

\section{Results and discussion}

\subsection{Bend loading test}

In the test, delamination failure occurred to the test specimen whose density of core material was $50 \mathrm{~kg} / \mathrm{m}^{3}$, and shear failure

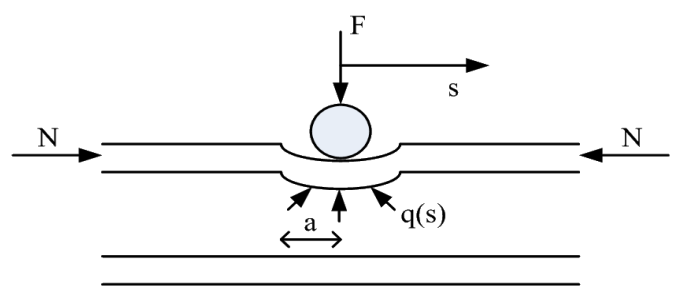

Fig. 1. The indentation failure of core material

occurred to the test specimens whose density of core material were $75 \mathrm{~kg} / \mathrm{m}^{3}$ and 100 $\mathrm{kg} / \mathrm{m}^{3}$ respectively. Fig. 2 shows the threepoint bending load-displacement curve of the sandwiches with different density of core material.

It could be noted from Fig. 1 that the glass fiber reinforced composite with different density of core material had different bearing capacity. The bearing capacity of the sandwich whose density of core material was $50 \mathrm{~kg} / \mathrm{m}^{3}$ was $250 \mathrm{~N}$, the smallest, but its deformation was $7 \mathrm{~mm}$, the largest. Among the three kinds of core materials, only the core material at the density of $50 \mathrm{~kg} / \mathrm{m}^{3}$ had deformed before loading, indicating that the core material at the density of $50 \mathrm{~kg} / \mathrm{m}^{3}$ was difficult to bear even its own load and was not suitable as the material which is required to have certain bearing capacity. The maximum bearing capacity of the sandwich whose density of core material was $75 \mathrm{~kg} / \mathrm{m}^{3}$ is $500 \mathrm{~N}$, which was twice that of the sandwich whose the density of core material was $50 \mathrm{~kg} / \mathrm{m}^{3}$. When the bearing load was maximum, the deformation was maximum, and the deformation displacement was $5 \mathrm{~mm}$. Unlike the sandwich whose density of core material was $50 \mathrm{~kg} / \mathrm{m}^{3}$, it had no deformation before loading, indicating that the sandwich could bear its own load and could be used in fields such as building. The maximum bearing capacity of the sandwich whose density of core material was $100 \mathrm{~kg} / \mathrm{m}^{3}$ was $1000 \mathrm{~N}$, which was twice that of the sandwich whose density of core material was $75 \mathrm{~kg} / \mathrm{m}^{3}$. When the load was maximum, the deformation was $2 \mathrm{~mm}$, and the bearing capacity of the sandwich whose density of core material was $100 \mathrm{~kg} / \mathrm{m}^{3}$ was maximum. Compared 


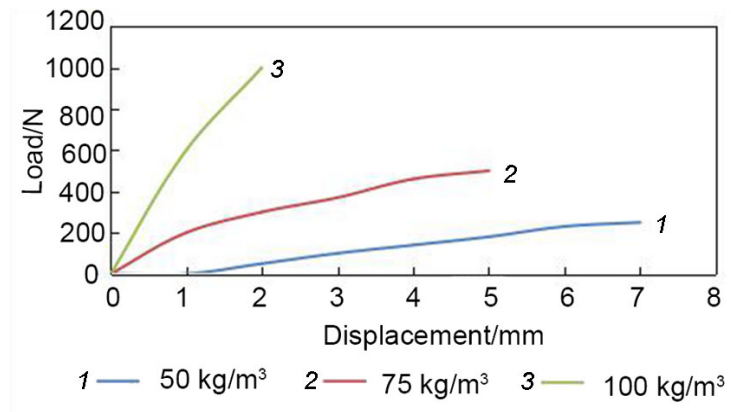

Fig.2. The three-point bending load-displacement curve of the sandwiches with different density of core material.

with the other two kinds of sandwich, it was more suitable to be a material which is required having certain weight. In summary, the bearing capacity of glass fiber reinforced composites increased, and the maximum deformation degree decreased with the increase of core density.

\subsection{Tensile performance under different} temperatures

- The tensile performance of PU at the density of $100 \mathrm{~kg} / \mathrm{m}^{3}$.

It could be seen from Table 2 that with the increase of ambient temperature, the temperature inside the PU rose, the maximum tensile load, tensile strength and tensile modulus decreased. Compared to the parameters under $20{ }^{\circ} \mathrm{C}$, the maximum tensile load, tensile strength and tensile modulus decreased $4.1 \%, 6.5 \%$ and $5.6 \%$, respectively, under $40{ }^{\circ} \mathrm{C}$, decreased $9.7 \%, 9.7 \%$ and $25.6 \%$, respectively, under $60{ }^{\circ} \mathrm{C}$, and decreased $39.2 \%$, $38.7 \%$ and $31.8 \%$, respectively, under $80{ }^{\circ} \mathrm{C}$. The reason for this phenomenon was that high temperature softened PU and enhanced its plasticity. The tensile modulus was one of the important parameters to measure the tensile properties of PU foam. The comparison of the tensile modulus of PU at different temperatures suggested that the decrease of modulus was not obvious; therefore temperature had little influence on the tensile performance of PU.

Table 2. The tensile test results of PU.

\begin{tabular}{|c|c|c|c|c||}
\hline Temperature $/{ }^{\circ} \mathrm{C}$ & 20 & 40 & 60 & 80 \\
\hline $\begin{array}{c}\text { The maximum } \\
\text { tensile load/N }\end{array}$ & 758.58 & 727.81 & 684.87 & 461.56 \\
\hline $\begin{array}{c}\text { Tensile } \\
\text { strength/MPa }\end{array}$ & 0.31 & 0.29 & 0.28 & 0.19 \\
\hline $\begin{array}{c}\text { Tensile } \\
\text { modulus/MPa }\end{array}$ & 12.61 & 11.90 & 9.34 & 8.60 \\
\hline \hline
\end{tabular}

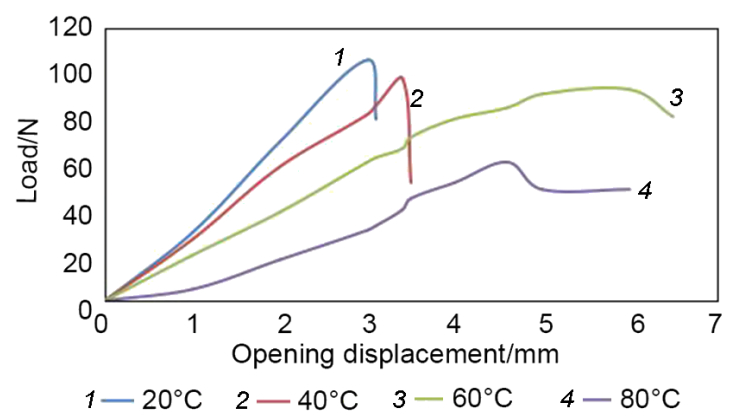

Fig.3. The load-displacement curve of the sandwich under four temperatures.

- The tensile performance of the sandwich under different temperatures.

Under different temperatures, different cracks generated on the binding interface between the glass fibre cloth and PU during loading. When the temperature was below $80{ }^{\circ} \mathrm{C}$, the crack was smooth, and the core material had no shear failure. When the temperature was higher than $80{ }^{\circ} \mathrm{C}$, the crack was not stable, and the core material had shear failure.

The load-displacement curve shown in Fig. 3 suggested that the load of the sandwich decreased with the increase of temperature under the same opening displacement. The decrease amplitude was the largest when the temperature was $80{ }^{\circ} \mathrm{C}$. For each test specimen under different temperatures, when the tensile displacement was maximum, the load of the sandwich under $20{ }^{\circ} \mathrm{C}, 40{ }^{\circ} \mathrm{C}, 60{ }^{\circ} \mathrm{C}$ and $80{ }^{\circ} \mathrm{C}$ was $106 \mathrm{~N}$, $98 \mathrm{~N}, 93 \mathrm{~N}$ and $61 \mathrm{~N}$, respectively.

- The strain energy release rate under different temperatures

Figure 4 shows the relationship between the strain energy release rate of the glass fibre reinforced composite sandwich and crack growth. The peak value of the strain energy release rate only appeared in cracks which was $40 \sim 50 \mathrm{~mm}$ long when the temperature was between $20{ }^{\circ} \mathrm{C}$ and $80{ }^{\circ} \mathrm{C}$, and the peak value increased with the increase of the temperature. When the temperature was below $40{ }^{\circ} \mathrm{C}$, the strain energy release rate was stable; the strain energy release rate of cracks which was $60 \sim 80 \mathrm{~mm}$ long had large fluctuation when the temperature was $60{ }^{\circ} \mathrm{C}$; the strain energy release rate had drastic change with the change of crack length when the temperature was $80{ }^{\circ} \mathrm{C}$, which was twice that of cracks under the other temperatures, and there was a fluctuation in cracks which was $60 \sim 80 \mathrm{~mm}$ long. The reason for the above phenomenon was that the resin used for bonding turned 
from glassy state to high-elastic state under the effect of high temperature, leading to discontinuous interface. It could be noted from Fig. 4 that the state transformation of resin started when the temperature was $60{ }^{\circ} \mathrm{C}$.

\section{Conclusions}

In this study, the bending performance of the glass fibre reinforced composite sandwich with different density of PU core material was tested using a microcomputer control electronic universal testing machine and three-point bending method, moreover the tensile performance of core material at a certain density under different temperatures and the sandwich which contained core material at that density were tested using a temperature box. The results were analyzed, and the conclusions were as follows.

The ultimate bearing capacity of the sandwich whose density of PU was 50 $\mathrm{kg} / \mathrm{m}^{3}$ was $250 \mathrm{~N}$, the smallest, its deformation was the largest, and the deformation displacement was $7 \mathrm{~mm}$. The ultimate bearing capacity of the sandwich whose density of PU was $75 \mathrm{~kg} / \mathrm{m}^{3}$ was $500 \mathrm{~N}$, and the maximum deformation displacement was 5 $\mathrm{mm}$. The ultimate bearing capacity of the sandwich whose density of PU was $100 \mathrm{~kg} / \mathrm{m}^{3}$ was $1000 \mathrm{~N}$, and the maximum deformation displacement was $2 \mathrm{~mm}$.

The maximum tensile load, tensile strength and tensile modulus of the PU at the density of $100 \mathrm{~kg} / \mathrm{m}^{3}$ decreased with the increase of temperature, and the decrease was slow. The decrease of the tensile strength and module was not obvious. Therefore it was concluded that temperature had little influence on the tensile performance of PU.

The glass fibre reinforced composite sandwich whose density of PU was $100 \mathrm{~kg} / \mathrm{m}^{3}$ had different tensile performance under different temperatures. When the opening displacement of the glass fibre cloth and core material were the same, the tensile load decreased gradually with the increase of temperature. For each test specimen under different temperatures, the load of the sandwich was $106 \mathrm{~N}, 98 \mathrm{~N}, 93 \mathrm{~N}$ and $61 \mathrm{~N}$ at the temperature of $20,40,60$ and $80{ }^{\circ} \mathrm{C}$ respectively when the tensile displacement was maximum.

The strain energy release rate of the glass fibre reinforced composite increased with the increase of temperature, and the peak values

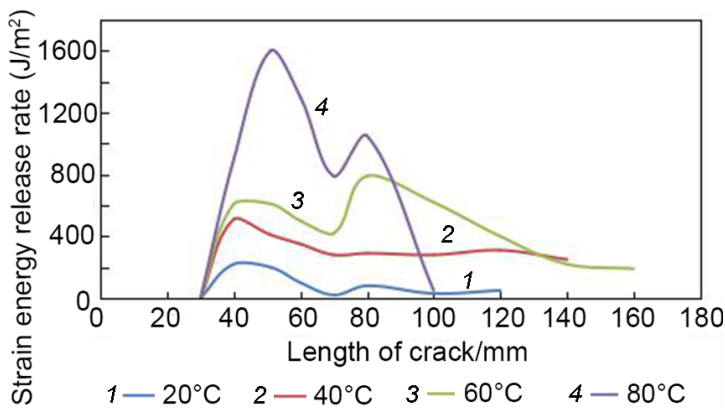

Fig.4. The strain energy release rate-crack length curve under different temperatures.

mostly appeared in cracks whose length was between $40 \mathrm{~mm}$ and $50 \mathrm{~mm}$. When the temperature was $40{ }^{\circ} \mathrm{C}$, the change of strain energy release rate was stable; the change of the strain energy release rate became larger when the temperature was $60{ }^{\circ} \mathrm{C}$ and intensive when the temperature was $80{ }^{\circ} \mathrm{C}$. The reason for the above phenomenon was that the resin used for bonding turned from glassy state to high-elastic state under the effect of high temperature.

\section{References}

1. S. Das, A. Hendrix, D. Stone, et al., Constr. Build. Mater., 93, 360 (2015).

2. A. Mostafa, K. Shankar, E. V. Morozov, Mater. Struct. 48, 1545 (2015).

3. B. C. Bal, I. Bektas, F. Mengeloglu et al., Constr. Build. Mater., 101, 952 (2015).

4. J. Vendramini, P. Mele, G. Merle, et al., $J$. Appl. Polym. Sci., 77, 2513 (2015).

5. A. Avdeeva, I. Shlykova, M. Antonova, et al. Transport Problems, 53, (2016).

6. Y. Ou, D. Zhu, Constr. Build. Mater., 96, 648 (2015).

7. J. M. L. D. Reis, Mat Res, 19, 183 (2016).

8. D. A. H. Jr, A. Haque, Proc. Engin., 105, 829 (2015).

9. J. M. Linden, G. Kotsikos, A. G. Gibson, Compos. Part A, Appl. Sci. Manufact., 81, 129 (2016).

10. O. Rodriguez, A. Matinmanesh, S. Phull, et al., J. Funct. Biomater., 7, 32 (2016).

11. C. Yang, J. S. Tomblin, L. Salah, J. Compos. Mater., 49, 3635 (2015).

12. R. Hemanth, B. Suresha, M. Sekar, J. Compos. Mater., 49, 2217 (2015).

13. A. Wargo, S. A. Safavizadeh, Y. R. Kim, Transp. Res. Record J. Transp. Res.Board, 2631, 123 (2017).

14. W. Huang, W. Zhang, N. Ye et al. Compos. Part B Engin., 97, 226 (2016).

15. B. Jiang, Z. Li, F. Lu, Compos. Struct., 133, 739 (2015). 